\title{
Improve Generic Skills of Science and Honesty of Students Through the Aceh Cultural Cooperative Model
}

\author{
Fitri Handayani ${ }^{1}$, Sahyar $^{2}$, Derlina $^{3}$, Bornok Sinaga ${ }^{4}$ \\ \{fitrihandayaniselian@gmail.com ${ }^{1}$ \} \\ Department of Universitas Negeri Medan Jl.Willem Iskandar Pasar V Medan Estate, Indonesia ${ }^{1,2,3,4}$
}

\begin{abstract}
The purpose of this study is (1) to improve generic science skills through an Aceh-based cooperative culture model on physics material. (2) Increase the honesty of students in the learning process through a cooperative culture based in Aceh. (3) To improve students' understanding of culture. The sample of this study was taken 1 (one) class. The research sample was applied to students of class XI IPA 1 Kutacane 1, Bambel sub-district, Aceh Tenggara district, which consisted of 37 students. Classes will be applied to learning through Acehnese culture-based cooperative learning models. Data collection techniques through generic science skill observation sheets are expressed in the number of mean values, and N-Gain values. Data processing to measure student honesty is to calculate the percentage of each indicator of student honesty questionnaire. Student response data were obtained using the student response questionnaire. The results of the study enhance students' generic science skills through a cooperative model based on Aceh culture physical material with a normal gain of 0.72 in the high category. Honesty students are obtained using an honest questionnaire, the openness of teachers and students in the learning process can improve students' sense of honesty. The positive response of students reaches $90.8 \%$.
\end{abstract}

Keywords: Cooperative based on Aceh culture, generic science skills, Honesty of Students

\section{Introduction}

Physics is learning science related to the natural surroundings. Physical science learning cannot be separated from laws, concepts, and theories that are fundamental. The demands of science learning on eraglobal according to the National Science Teachers Association (2006) are to prepare students with various skills and skills such as creative thinking, innovative, critical, problem solving, communication, collaboration, ICT Literacy and leadership. Science learning must also prepare qualified students, namely science-aware students, have high-level values, attitudes and thinking skills so that human resources will emerge that can think critically, think creatively, make decisions, and solve problems (Hadi, 2017).

Based on the Minister of National Education Regulation (Ministry of National Education, 2006) No. 22 of 2006 the purpose of physics lessons in high schools are: (1) forming a positive attitude towards physics by realizing the order and beauty of nature and promoting the greatness of God Almighty, (2) fostering a scientific attitude that is honest, objective, open, resilient, critical and able collaborate with others, (3) develop experience to 
be able to formulate problems, propose and test hypotheses through experiments, collect, process, and interpret data, and communicate the results of the experiment orally and in writing, (4) develop reasoning skills in thinking inductive analysis and deductive by using concepts and principles of physics to explain various natural events and solve problems both qualitatively and quantitatively, (5) master the concepts and principles of physics and have the skills to develop knowledge, and the attitude of confidence as a provision for continuing education at a higher level.

Education as an effort made to realize the learning and learning atmosphere, so that students actively develop their potential to have religious spiritual strength, self-control, personality, intelligence, noble character, and skills needed by themselves, society, nation and state. Facing the current era of globalization requires reliable human resources who have high self-confidence, are able to solve problems that have, have a high sense of curiosity, diligent, appreciate the work of knowledge and have the willingness to cooperate. Education is the most important part of life. The quality of a nation's education influences the progress of the nation.

Efforts to improve the quality of education are continuously carried out both conventionally and innovatively. This is more focused after being mandated in Law No. 20, 2003 article 3 that the aim of national education is to develop the potential of students to be human beings who are faithful and devoted to God Almighty, noble, healthy, knowledgeable, capable, creative, independent, and become democratic citizens who are responsible and responsible.

Education has problems that are core to the learning process. Learning is a process of interaction between students and educators and learning resources in the learning environment (Law No. 20 of 2003 concerning National Education System). The learning process is the implementation of a series of planning that has been carried out by the teacher in the form of interaction with students inside and outside the classroom to achieve goals. In this condition there is a series of actions of the teacher and students on the basis of reciprocal relationships that take place in an eductive situation.

The ever increasing era of globalization can influence students' character quickly. From the results of interviews with teachers at high school 1 Kutacane Aceh Tenggara stated: the low curiosity of students, low honesty of students, not thinking critically, low interest in students 'learning in physics subjects, low students' interest in solving physical problems. Students assume that physics learning is very difficult to see from formulas, theories, concepts, and principles.

As a result of the problems resulting in low physics learning outcomes under the KKM with an average grade of 70.00 and a lack of collaboration in learning seen in the teaching and learning process during observation. Though learning science in principle is not enough to simply memorize a concept through textbooks, more than that learning science is essentially a process and product. Learning science can be done in a variety of ways, such as observing / observing an object or natural phenomenon, taking measurements, making hypotheses, designing, testing data, discussing groups and conducting experiments.

Generic skills are very important for students because this ability is needed by students in developing careers in the future in accordance with their respective fields, especially in the field of science. Generic abilities are not suddenly obtained but these skills must be continuously trained to increase. The purpose of increasing generic science skills is that the knowledge and skills gained from learning outcomes in the teaching and learning process can be applied in real life and answer the challenges of the times that are growing faster, especially in terms of science and technology. In learning, generic science skills must 
be adapted to the model or method of learning, so that it is more effective in seeing improvements that occur.

According to Kamsah in (Rosidah 2017) states that generic skills are employability skills used to apply knowledge. Thus, generic skills are also skills needed for various fields of work and life. In addition, generic skills are also skills that result from intellectual abilities combined with psychomotor skills so as to produce attitudes that will be attached throughout life.

Efforts to realize a learning atmosphere are more emphasized to create conditions and preconditions so that students learn, while the learning process prioritizes efforts to achieve learning goals or student competencies. In the learning process, teachers are required to be able to learn, which includes planning, implementing, and evaluating learning. This is in accordance with Republic of Indonesia Regulation No. 41 of 2007 concerning Standard Processes.

Education for Indonesia is an integral part of national development and one of the determinants of successful development in all fields. One proof of the efforts made by the government to improve the quality of education is to implement the 2013 curriculum. The 2013 curriculum puts culture into one of the components developed from the elementary school to high school level.

Education and culture is something that cannot be avoided in everyday life, because culture is a whole and whole entity that applies in a society and education is a basic need for every individual in society. Education and culture have a very important role in fostering and developing the noble values of the nation, which has an impact on character formation based on noble cultural values. Like Tilaar (in Suryana 2015) states that culture is a complex totality that includes knowledge, beliefs, art, law, morals, abilities and habits that are obtained by people as members of society.

Character education not only aims to improve students' understanding, but also more important to produce young people who have the ability to become agents of change, character and culture. Character and cultural education has become an important issue in the curriculum at various levels. According to Chang (2009), the most important factor in the formation of children's character is how children deal with problems in the surrounding environment. One of them is by educating students to analyze character, culture and social values. Implementation in 2013 The curriculum in Indonesia focuses on developing student character, facing challenges, especially in difficulties. Teachers in integrating approaches develop the character of students in learning.

Integrating education and culture in the learning process will create meaningful learning. Because the process of culture-based learning not only transfers culture and cultural embodiment but uses culture to make students able to create meaning, penetrate the limits of imagination, and be creative in achieving a deep understanding of the subjects being studied, especially physics subjects as part of science knowledge.

Sardjiyo \& Pannen (2005) stated that culture-based learning is a strategy for creating learning environments and designing learning experiences that integrate culture as part of the learning process. Culture-based learning is based on the recognition of culture as a fundamental part (fundamental and important) for education as an expression and communication of an idea and the development of knowledge. Culture that is integrated in the various cultural contexts in the land of Aceh.

Learning device is a tool or material used to carry out the learning process. Therefore, it is better for learning devices to be prepared using scientific methods. One of them is arranging learning tools based on Cooperative Learning learning models. Trianto (2011) stated 
that the learning tools needed to manage the teaching and learning process can be: syllabus, Learning Implementation Plans, Student Activity Sheets, Learning Evaluation Tests, learning media and student textbooks. Based on Permendikbud number 22 of 2016 concerning the Standard Process for Primary and Secondary Education, it is stated that the preparation of learning tools is part of the planning of learning. Learning planning is designed in the form of a Syllabus and Learning Implementation Plan which refers to the Content Standards. Learning planning includes the preparation of learning plans and preparation of media and learning resources, learning assessment tools, and learning scenarios.

The learning device must be accompanied by an appropriate learning model and the most likely to be applied in appropriate learning is the cooperative learning model. According to Slavin (2005) cooperative is a learning model where students learn and work in small groups collaboratively with heterogeneous group structures. This learning model is a form of learning based on constructivist notions. Cooperative learning is a collaborative learning strategy where groups of small students with different levels of ability work together to achieve common goals or complete group assignments as well as goals and tasks that they cannot complete on their own.

Integration of Aceh's cultural context into physics learning can provide opportunities for teachers to improve the generic abilities of student science and honesty of students and introduce various kinds of Acehnese cultural contexts that are close to the child's environment, so that the culture is preserved and opportunities for development remain open in the school environment . Learning in schools that is separate from the local culture can lead students to be separated from the roots of their community culture, which in turn will make students not have good skills to participate in solving local problems that require methods and methods that are inherent in customs and customs. where is the student going through his life later.

According to Kamsah in (Rosidah 2017) states that generic skills are employability skills used to apply knowledge. Thus, generic skills are also skills needed for various fields of work and life. In addition, generic skills are also skills that result from intellectual abilities combined with psychomotor skills so as to produce attitudes that will be attached throughout life. Indicators of generic science skills used are direct observation, indirect observation, awareness of scale, symbolic language, logical frame, logical consistency, causal law, modeling, logic inference, abstraction.

\section{Research Purposes}

(1) To improve generic science skills through a cooperative culture model based on Aceh on physics material. (2) To increase student honesty in the learning process through a cooperative culture based on Aceh. (3) To improve students' understanding of culture.

\section{Research Sample}

According to Sudjana (2005) states the sample is a part taken from the population. The sample of this study was taken 1 (one) class. The research sample was applied based on the problem to solve the problem need an action, so the research sample was applied in class XI IPA 1 Kutacane 1 State High School, Bambel sub-district in Southeast Aceh district the 
students consisted of 37 students. The class will be applied to learning through Aceh culturebased cooperative learning models.

\section{Data Analysis Techniques For Generiks Science Skills And Student Honesty}

Instrument data were analyzed to determine the improvement of generic science skills and student honesty. Data analysis techniques to improve generic science skills and student honesty in this study are:

\subsection{Descriptive Analysis}

The research data in the form of students' generic science skills are expressed in the number, average, and N-Gain values. Generic science skills are assessed at each meeting and the honesty of students is assessed after the application of learning tools using the Acehnese culture-based cooperative learning model.

\subsection{Inferential Analysis}

\subsubsection{Increased Generic Skills of Science}

The data processing of the generic science observation skill sheet was intended to determine the generic science skills of students, while the gain calculation and normalized gain scores were intended to determine the improvement of generic science skills in the application of learning devices using the Acehnese culture-based cooperative learning model. The steps taken to measure the test score are:

1. Scoring

Giving a score by giving a score weight from 1 to 3 adjusted to the predetermined scoring criteria. The score of each student was determined by looking at the students' generic science skills based on observation sheets and rubrics that had been developed. This scoring process is carried out when students carry out experiments at each meeting.

2. Calculation of Gain scores and normalized gain

Knowing the increase in generic science skills developed through learning is calculated based on the normalized gain score. This is intended to avoid mistakes in interpreting the gain of each student. The normalized gain score is used by the formula developed by Hake, namely:

$$
g=\frac{S_{P o s}-S_{\text {Pre }}}{S_{M a k}-S_{\text {Pre }}}(\text { Hake, 1999) }
$$

Information:

g: gain

Spos:posttest score

Spre:pretest scores

Smak :maximum score

with the N-gain acquisition category (Hake, 1999) shown in Table 1.1. 
Table 1. Average Value of Normalized Gain

\begin{tabular}{cc}
\hline Gain $\langle\mathrm{g}\rangle$ & Criteria \\
\hline$\langle\mathrm{g}\rangle \geq 0,7$ & High \\
$0,7\rangle\langle\mathrm{g}\rangle \geq 0,3$ & Medium \\
$\langle\mathrm{g}\rangle<0,3$ & Low \\
\hline
\end{tabular}

4.2.2

\section{Increase Student Honesty}

Assessment of student honesty is done using a rating scale questionnaire in the form of a numerical scale. This questionnaire was conducted to measure the honesty of students during the learning process by using a cooperative learning model based on Aceh culture.

Data processing to measure student honesty is by calculating the percentage of each indicator of student honesty. The steps taken to process student honesty questionnaire data are as follows:

a. Calculate the number of each type of aspect of the indicator assessed

b. Calculate the percentage of each type of aspect of the honesty indicator of students who are assessed using the formula:

$\%=($ Number of students who meet the criteria $) /($ number of all students $) \times 100 \%$

c. After calculating the percentage of each aspect of the indicator, then compare the most dominant percentage of each aspect of the indicator at each meeting.

\subsubsection{Student Response Questionnaire}

Student response data were obtained using student response questionnaires. Data was obtained by means of students giving a checklist $\sqrt{ }$ in the available column for each question asked. Response questionnaire is given to students at the end of learning activities using the instruments provided. This questionnaire is used to obtain data about the level of student interest in LKS and student responses. The responses of students who want to know are:

a. Students' feelings about the components of the subject matter, Student Activity Sheet (LKS), learning atmosphere in the classroom, and how to teach the teacher (happy or not happy).

b. Students' opinions on the components of the subject matter, student activity sheets (LKS), generic science skills worksheets, honesty questionnaires, classroom learning atmosphere, and teacher teaching methods (new or not).

c. Students' interest in further learning activities, if learning is carried out as has been followed now.

d. Students 'opinions about the language used in the worksheet are generic skills of students' physics, student honesty questionnaires and worksheets (understandable or not).

e. Students 'opinions about the appearance (writing, illustration, picture, layout of images) contained in the worksheets of students' generic science skills, student honesty questionnaires and worksheets (interesting or not interesting).

\subsubsection{Interview}


Interviews are conducted to find out things that are less observable at the time of observation. The questions asked are prepared with certain guidelines referring to aspects or things that will be examined, in this case students' understanding of physics learning.

\section{$5 \quad$ Research Results And Discussion}

Lessons learned from the learning process through cooperative learning models based on Acehnese culture in each learning process using aspects of the students respond when the teacher gives apperception. Students who discuss the material delivered by the teacher, Students work on LKS, Students discuss with the group, at the precisely the Acehnese culturebased cooperative learning model and students present the results of group discussions. Then the results of the study:

\subsection{Genetic Science Skills}

In the study of physics science using the Acehnese culture-based cooperative model on students' generic science skills has increased. Improving students' generic science skills through a cooperative model based on Acehnese culture on physical material with a normal gain of 0.72 with a high category.

\subsection{Honesty of Students}

Honesty of students is obtained by using honesty questionnaires. After the learning activities are complete the students are given an honesty questionnaire filled by students. Five indicators of student honesty, namely 1) Not cheating or cheating, 2) Expressing their feelings, 3) Expressing right / wrong attitude towards the material during group discussion, 4) Courage and confidence in answering the teacher's questions, 5) Calm and understand the task of the teacher. Based on the five indicators of honesty students experience positive changes. Openness of teachers and students in the learning process can improve students' sense of honesty.

\subsection{Student Response}

The positive response of students reaches $90.8 \%$. Student activities in learning at each meeting have increased. Previous research carried out related to culture-based learning in science or physics learning namely the findings of Wahyudi (2003) who conducted a study of cultural aspects of physics learning and the importance of a culture-based physics curriculum gave a conclusion that students 'cultural background had an influence on students' learning process in school. Coupled with Suastra (2005) reveals that ethnoscience that lives and develops in society is still in the form of concrete experiential knowledge as a result of the interaction between its natural and cultural environment.

The goal of physics learning based on Aceh's cultural context is to help students become aware of how students can think mathematically according to their culture and traditions. In addition, increasing the generic ability of science and honesty of students through the context of Aceh culture can make teachers and students undergo a fun learning process, because in a culture of culture-based learning, teachers and students actively 
participate based on the culture they have known so far so that learning outcomes are more optimal.

\section{Conclusion}

Based on the results of the analysis and discussion in this study, some conclusions are presented as follows:

(1) Improving students' generic science skills through an Acehnese culture-based cooperative model on physical material with a normal gain of 0.72 in the high category. The increasing honesty of students in learning through the Acehnese culture-based cooperative model on physics material has increased several indicators of student honesty seen from the improvement of each meeting, namely on the following indicators: a) Not cheating or scanning, b) Expressing his feelings, c) Expressing righteousness / wrong with the material during group discussion, d) Dare and confident answer the teacher's questions, e) Calm and understand the work of the teacher's tasks (2) The positive response of students reaches 90.8\%. Student activities in each learning meeting have increased through Acehnese culturebased cooperative learning models. (3) The increase in students' understanding of culture can be seen from the results of interviews conducted after the teaching and learning process is completed so as to increase the attractiveness of students in learning physics. The cultural elements that are associated in learning are seen in terms of food, games, dances, traditional clothing, philosophy and so on. 


\section{References}

[1] Akbar, S.: Learning Instrument Instrument. (2013)

[2] Arends.R I.: Learning to Teach. (2008)

[3] Arends, R. I.: Learning for Teaching.Book 2. (2013)

[4] Arikunto, S.: Research Procedure A Practical Approach. (2009)

[5] Asmin, \&Abil, M.: Measurement and Assessment of Learning Outcomes by Classical and Modern Analysis. (2014)

[6] Beladina, N., Suyitno, A., and Khusni K.: Effectiveness of CORE LKPD Learning Models on Student Mathematical Creativity. Vol. 2, pp. 34-39. Journal of Mathematics Education, Unnes (2013)

[7] Gay, G.: Culturally responsive teaching: Theory, practice, and resesarch. (2000)

[8] Hadi, K.: Development of Problem Based Learning Model Based on Loans Wisdom in Class X Biodiversity Material in South Aceh Regency. Vol. 4, pp. 42-52. Bionatural Journal (2017)

[9] Herman.: Development of Direct Teaching Model Learning Tools for Teaching Solid Material Equilibrium Material. Vol.8, pp. 1-11. Journal of Science and Physical Education (2012)

[10] Hake, R. R.: Hake, R. R. pp. 1-4 (1999)

[11] Joyce, B., \& Weil, M.: Models of Teaching (Fifth Edition teaching models). (2003)

[12] Ministry of National Education.: Education Unit Level Curriculum Model. (2006)

[13] Ministry of National Education.: Effective Learning. (2005)

[14] Ministry of National Education.: RI Law No. 20 of 2003 concerning the National Education System (2003)

[15] Ministry of Education and Culture.: Republic of Indonesia Minister of Education Regulation (2014)

[16] Ministry of National Education.: Action Plan for National Assessment of Character Education. (2010)

[17] Koentjaraningrat.: History of Anthropological Theory 1 (2009)

[18] Krasnoff, B.: Culturally Responsive Teaching A Guide to Evidence-Based Practices for Teaching All Students Equitably (2016)

[19] Martono, A. H., Suparmi, Aminah, S. N.: Development of Class X Physics Learning Outcomes Assessment Instrument on Newton's Legal Material and Its Implementation Based on 2013 Curriculum. Vol. 5. Journal of Inquiry (2016)

[20] Government Regulation.: concerning National Education Standards (2005)

[21] Minister of Education and Culture.: Technique and form of assessment instruments Based on the 2013 curriculum (2013)

[22] Rahmawati, Y.: The Role of Transformative Learning in Chemical Education: Character Development, Cultural Identity, and 21st Century Competence. pp. 1-16 (2017)

[23] Rosidah, T., Astuti, P. A., Wulandari, A.: Exploration of Generic Science Skills of Students in Chemistry Subjects at SMA Negeri 9 Semarang. Vol. 5, pp. 130-137. Journal of Science Education (JPS) (2017)

[24] Rusman.: Learning Models to Develop Teacher Professionalism (2011)

[25] Samani, M. Hariyanto.: Character Education (2012)

[26] Slavin, R.: Educational Psychology, Theories and Practice.Eighth Edition (2006)

[27] Sanjaya, W.: Education-Oriented Standards Process Oriented Strategies (2008)

[28] Sanjaya, W.: Education Process Oriented Learning Standards Strategy (2010)

[29] Sardjiyo.Pannen, P.: Culture-based learning: learning innovation models and implementation of competency-based curriculum. Vol. 6, pp. 83-97. Educational journal (2005)

[30] Slavin, Robert E.: Cooperative Learning: theory, research and practice (N. Yusron. Translation) (2005)

[31] Suastra, I. W.: Reconstructing original science (indigenous science) in order to develop local culture-based science education in schools, dissertations, Indonesian (2005) 
[32] Sudarmin, D.: Generic Skills of Science and Its Application in Organic Chemistry Learning (2012)

[33] Sudjana, N.: Assessment of the Results of the Teaching and Learning Process (2005)

[34] Suryana, Y.D., Rusdiana, A.H.: Multicultural Education (2015)

[35] Trianto.: Constructivistic Oriented Learning Models (2011)

[36] Trianto.: Integrated Learning Model (2010)

[37] Trianto.: Designing Innovative - Progressive Learning Models (2009)

[38]Trianto.: Integrated Learning Models, Concepts, Strategies, and Their Implementation in Education Unit Level Curriculum (KTSP) (2013)

[39] Umar, M.: Aceh Civilization (2009)

[40] Wahyudi.: Overview of Cultural Aspects of Natural Science Learning: The Importance of a Local Culture-Based Science Curriculum. pp. 42-59. Journal of education and culture (2003) 